\title{
COMO CONSULTAR A RELAÇÃO DOS PROGRAMAS INSCRITOS
}

A apresentação dos 1.191 programas, projetos ou atividades inscritos no Ciclo de Premiação 2004 do Programa GESTÃo PÚBLICA E CIDADANIA está ordenada, nesta publicação, a partir das áreas e sub-áreas de atuação governamental. É preciso deixar claro que a inserção de tais programas nas áreas propostas admite diversas possibilidades, cabendo aos responsáveis pela inscrição sua própria classificação. O Programa GESTÃo PÚBLICA E COOADANIA procurou classificar apenas as inscrições que apresentavam informações incompletas ou insuficientes. Portanto, é possível que sejam encontrados programas, projetos ou atividades típicos de determinada área de ação governamental (ex.: educação, finanças e orçamento público etc.) em áreas correlatas (ex.: criança e adolescente, participação popular etc.). Tornase conveniente, portanto, que os interessados em determinada área consultem também outras, para que se possa obter uma visão mais abrangente das inscrições no Ciclo de Premiação 2004.

Dentro de cada área, os programas, projetos ou atividades estão ordenados numericamente, de acordo com a data de chegada dos questionários respondidos. A apresentação de cada programa, projeto ou atividade inclui o rol de informações apresentado no quadro a seguir.

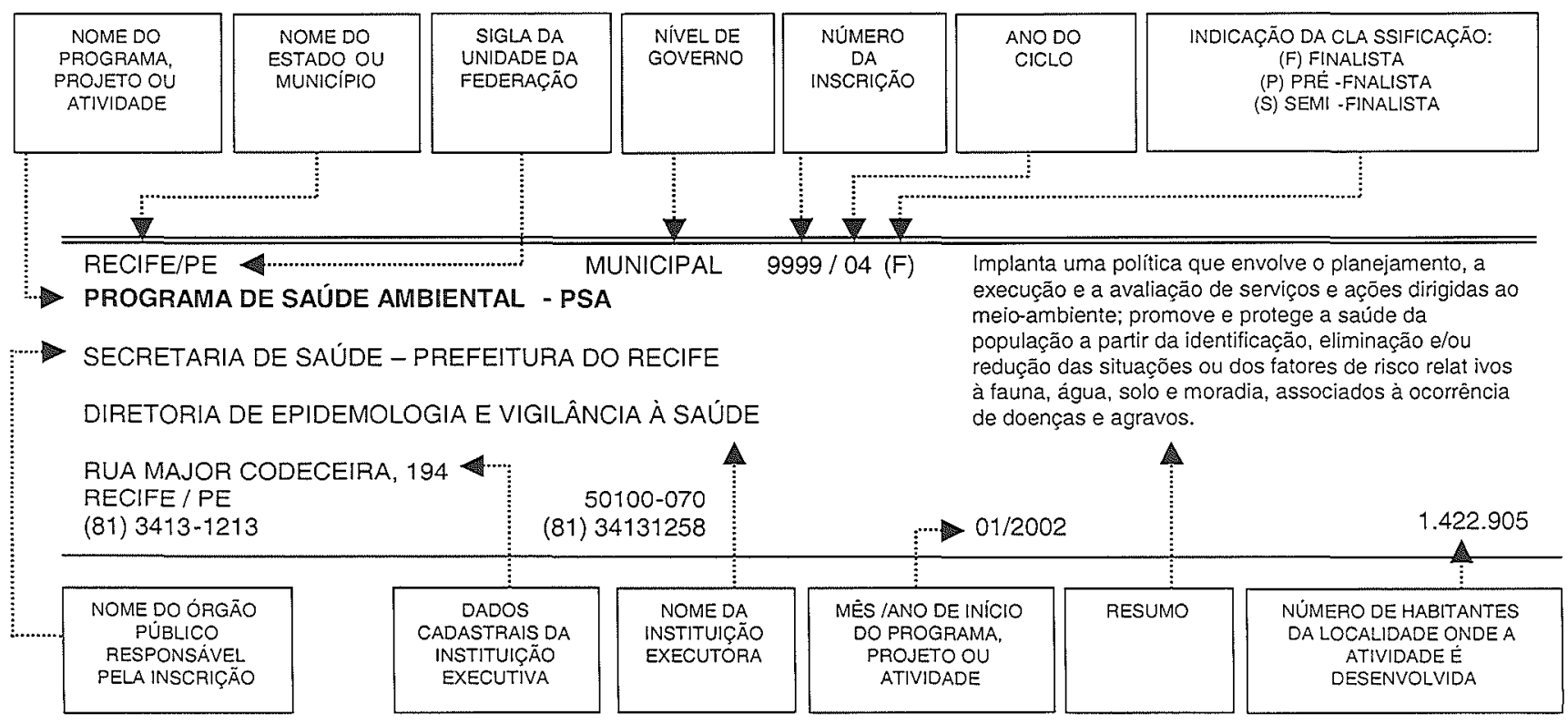


